\title{
Utility of SPECT/CT in Sentinel Lymph Node Detection in a Case of Vulvar Carcinoma
}

\author{
Vulva Kanserli Bir Olguda Sentinel Lenf Dügüüü Saptanmasında Spect/Ct'nin Yeri
}

\author{
Chidambaram Natrajan Balasubramanian Harisankar1, Bhagwant Rai Mittal1, Anish Bhattacharya1, Lakhbir Kaur Dhaliwal2 \\ I Postgraduate Institute of Medical Education and Research, Nuclear Medicine and PET, Chandigarh, India \\ 2Postgraduate Institute of Medical Education and Research, Obstetrics and Gynaecology, Chandigarh, India
}

\begin{abstract}
Minimally invasive sentinel node biopsy is associated with significantly less morbidity and has been evaluated in several studies in patients with gynecologic malignancies. Accurate identification of the sentinel lymph nodes is possible in most of the patients. Hybrid SPECT/CT is a newer modality which has been shown to improve the localization of the suspicious lesions and also provide anatomical information of the involved lymph nodes. We report the utility of hybrid SPECT/CT in localization of sentinel lymph node in a case of vulvar cancer and its impact on patient management.
\end{abstract}

Key words: Sentinel lymph node biopsy, Single -Photon Emission Computerized Tomography, , Computeized Tomography, X Ray, Lymphoscintigraphy, Vulvar cancer

\begin{abstract}
Özet
Minimal invaziv sentinel düğümü biyopsisi daha az morbidite ile ilişkilidir ve jinekolojik malignitesi olan hastalarda çeşitli çalışmalarda değerlendirilmiştir.. Hastaların çoğunda sentinel lenf düğümlerinin hassasiyetle tanımlanması mümkündür. Hibrid SPECT/CT şüpheli lezyonların lokalizasyonu kolaylaştırdığı ve aynı zamanda tutulum olan lenf nodları ile ilgili anatomik bilgi sağladığı gösterilmiş olan yeni bir yöntemdir. Bu yazıda, hibrid SPECT/CT'nin vulvar kanserli bir olguda sentinel lenf nodunun lokalizasyonu ve hasta yönlendirilmesine katkısı sunulmaktadır.

Anahtar kelimeler: Sentinel Lenf Nod Biyopsisi, Tek Foton Emisyonlu Bilgisayarlı Tomografi, Bilgisayarlı Tomografi, X Işını, Lenfosintigrafi, Vulva Kanseri
\end{abstract}

\section{Introduction}

The use of lymphatic mapping and sentinel node detection for cutaneous melanoma and breast cancer has been extensively investigated, and now minimally invasive sentinel node biopsy, which is associated with significantly less morbidity, has successfully replaced complete nodal dissection for nodal staging. This minimally invasive approach has been evaluated in several studies in patients with gynecologic malignancies, which have shown it to be capable of accurately identifying sentinel nodes. SPECT/CT provides both anatomical and functional information about the sentinel lymph node. We report the utility of hybrid SPECT/CT in localization of sentinel lymph node in a case of vulvar cancer.

\section{Case report}

A 40 year old female presented with bleeding vulvar ulcer on the right side (T1 stage tumor). A biopsy from the

Address for Correspondence: Bhagwant Rai Mittal MD, Deptt.of Nuclear Medicine \& PET, PGIMER, Chandigarh - 160012 , India Phone: +91 1722756722 E-mail: brmittal@yahoo.com Received: December 01, 2011 Accepted: February 21, 2012 


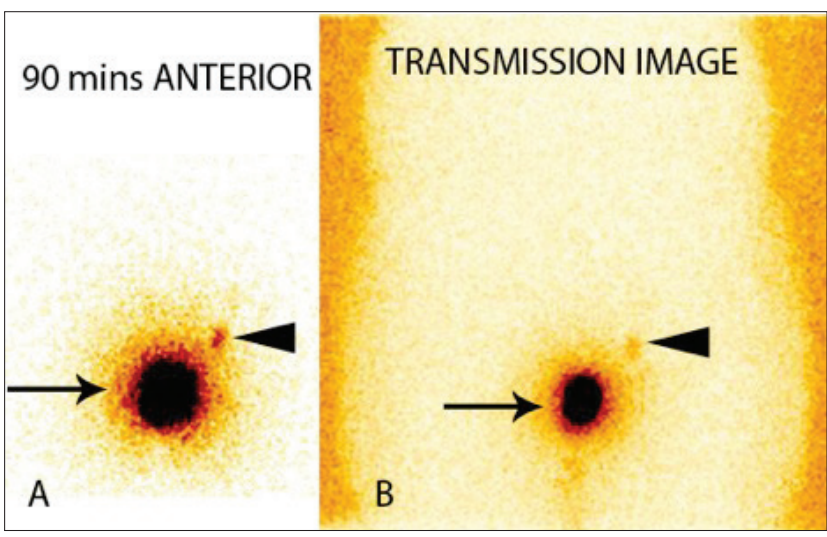

Figure 1. Static planar images acquired in anterior view without $(A)$ and with transmission source (B). Intense tracer activity at the site of injection (arrows). Faint tracer activity in the left inguinal region (arrow heads) is noted at 90 minutes.

edge of the ulcer revealed squamous cell carcinoma. The patient was planned for definitive surgery. A sentinel lymph node dissection was planned. Methylene blue dye was not used. Technetium-99m labeled unfiltered sulfur colloid was used and injection performed on the day of the surgery. Radiotracer in a dose of 100 microcurie each was injected at four sites around the tumor. Multiple static images were acquired till the visualisation of the sentinel lymph node. A hybrid SPECT/CT was performed immediately after visualisation of the sentinel lymph node. A focus of tracer uptake was noted in the planar image in the left inguinal region at $90 \mathrm{~min}$ after the injection. SPECT/CT localized the tracer uptake in a $1.2 \mathrm{~cm}$ sized left inguinal lymph node (Figure 1 and 2). The exact anatomical location of the lymph node and its relation with the adjacent structures were also defined by SPECT/CT. The left inguinal lymph node was successfully localized with an intra-operative probe and was subjected to histopathological examination. No metastases were noted in the lymph node on pathological examination. An unnecessary lymphadenectomy was avoided and the patient is on follow up without evidence of disease progression.

\section{Discussion}

Finding of positive sentinel nodes at surgery significantly influences staging and subsequent clinical management. In particular, a sentinel lymph node free from tumor metastasis would exclude tumor spread to the at-risk regional lymphatic basin. Although it is possible that a negative sentinel lymph node corresponds to metastatic involvement of a second-tier lymph node, this occurrence is very rare, especially when the primary tumor is in an early stage of growth. The sentinel node concept remains thus valid in most patients.

Studies have shown the efficacy of sentinel node mapping in cutaneous melanoma $(1,2)$. Sentinel node mapping has been shown to be effective in gynecologic malignancies $(3,4)$ including vulvar cancer $(5,6)$. The accurate localization of sentinel nodes for tissue sampling has become increasingly important for clinical management. Preoperative SPECT/CT lymphoscintigraphy is ideal in this regard because it can map unpredicted lymphatic drainage pathways within the complex pelvic anatomy $(7,8)$. SPECT/ $\mathrm{CT}$ is able to achieve the precise anatomic localization of sentinel nodes on cross-sectional imaging, especially in relation to known anatomic structures such as the femoral or saphenous vein, information that is critical in planning the surgical approach. SPECT/CT also increases the sensitivity of sentinel node detection (9). A node close to the injection

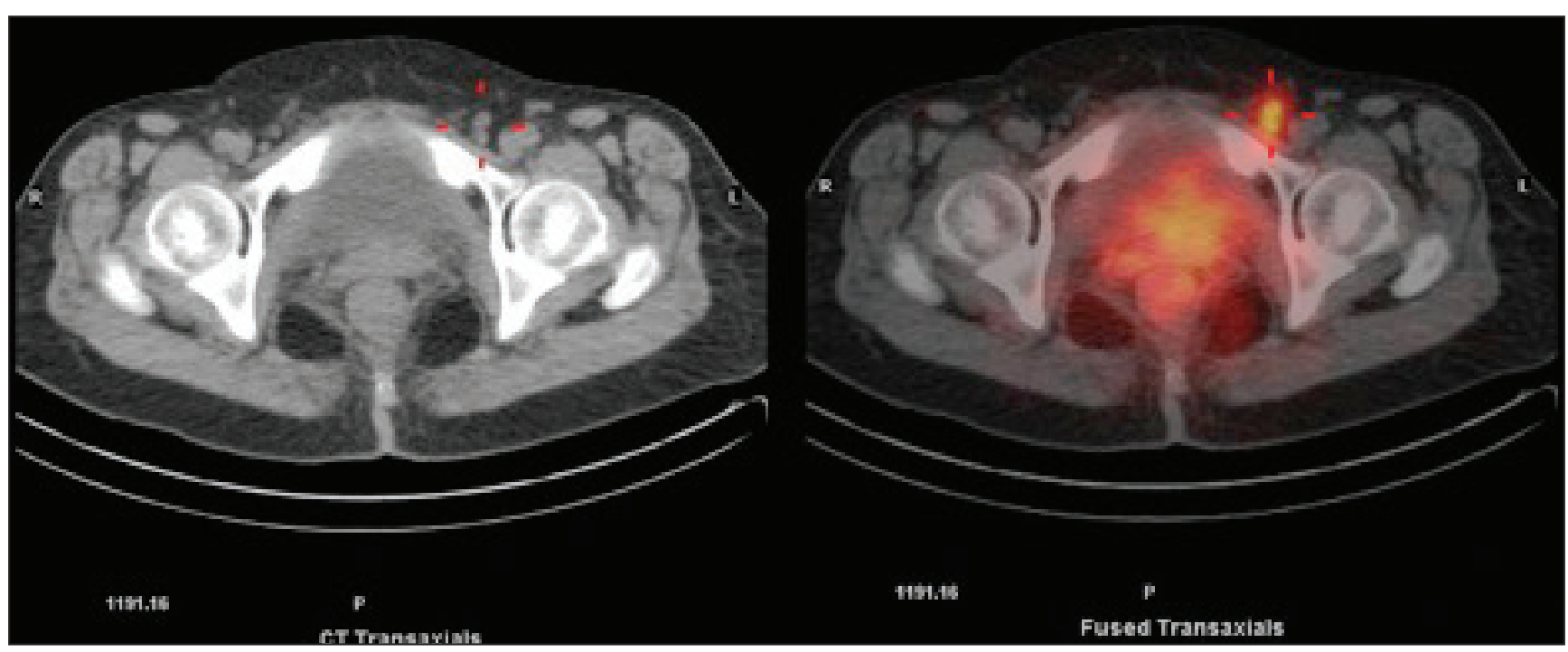

Figure 2. Hybrid SPECT/CT images of the pelvis showing focal tracer uptake in small left inguinal lymph node (Triangulation). Also noted is intense tracer activity in the vulva (site of injection) 
site can also be masked as the result of strong activity from the injection site (ie, the "shine through" effect). SPECT/CT avoids this problem and improves the detectability of the lesion (10). SPECT/CT has the potential to revive the usage of sentinel lymph node dissection.

\section{References}

1. Thompson JF, Shaw HM. Sentinel node mapping for melanoma: results of trials and current applications. Surg Oncol Clin N Am 2007; 16:35-54.

2. Hill $A D$, Tran $K N$, Akhurst $T$, Yeung $H$, Yeh $S D$, Rosen PP, Borgen $\mathrm{PI}$, Cody HS 3rd. Lessons learned from 500 cases of lymphatic mapping for breast cancer. Ann Surg 1999; 229:528-535.

3. Levenback $C$, Coleman RL, Burke TW, Lin WM, Erdman W, Deavers M, Delpassand ES. Lymphatic mapping and sentinel node identification in patients with cervix cancer undergoing radical hysterectomy and pelvic lymphadenectomy. J Clin Oncol 2002;20:688-693

4. Frumovitz $\mathrm{M}$, Bodurka DC, Broaddus RR, Coleman RL, Sood AK, Gershenson DM, Burke TW, Levenback CF. Lymphatic mapping and sentinel node biopsy in women with high-risk endometrial cancer. Gynecol Oncol. 2007;104:100-103.
5. Freudenberg LS, Görtz E, Hagen C, Harms E, Koska WW, Marlowe RJ, Shadouh S, Stock C. Lymphatic mapping using SPECT/CT in vulvar carcinoma. Clin Nucl Med 2010;35:950-952.

6. Devaja O, Mehra G, Coutts M, Adamson S, Montalto SA Donaldson J, Papadopoulos AJ. A Prospective Study of Sentinel Lymph Node Detection in Vulval Carcinoma. Is It Time for a Change in Clinical Practice? Int J Gynecol Cancer 2011;21:559564.

7. Abramova L, Parekh J, Irvin WP Jr, Rice LW, Taylor PT Jr, Anderson WA, Slingluff $\mathrm{CL}$ Jr. Sentinel node biopsy in vulvar and vaginal melanoma: presentation of six cases and a literature review. Ann Surg Oncol 2002:9:840-846.

8. Frumovitz M, Gayed IW, Jhingran A, Euscher ED, Coleman RL, Ramirez PT, Levenback CF. Lymphatic mapping and sentinel lymph node detection in women with vaginal cancer. Gynecol Oncol 2008;108:478-481

9. Kobayashi K, Ramirez PT, Kim EE, Levenback CF, Rohren EM, Frumovitz M, Mar MV, Gayed IW. Sentinel node mapping in vulvovaginal melanoma using SPECT/CT lymphoscintigraphy. Clin Nucl Med 2009:34:859-861.

10. Khafif A, Schneebaum S, Fliss DM, Lerman H, Metser U, Ben-Yosef R, Gil Z, Reider-Trejo L, Genadi L, Even-Sapir E. Lymphoscintigraphy for sentinel node mapping using a hybrid single photon emission CT (SPECT)/CT system in oral cavity squamous cell carcinoma. Head Neck 2006:28:874-879. 